\title{
Distribution Analysis of Doctors in Indonesia
}

\author{
Analisis Distribusi Tenaga Dokter di Indonesia \\ Agung Dwi Laksono', Ilham Akhsanu Ridlo², Ernawaty ${ }^{2}$ \\ ${ }^{1}$ National Institute of Health Research and Development, Indonesia Ministry of Health. \\ 2 Health Policy and Administration, Faculty of Public Health, Universitas Airlangga Surabaya \\ Email: agung.dwi.laksono-2016@fkm.unair.ac.id
}

\begin{abstract}
Introduction: The distribution of health workers was an important study in Indonesia which has a wide geographical range and challenges as an archipelagic country for the fulfillment of fair and equitable health services.

Aim: The study was conducted to answer factors related to the distribution of doctors based on provinces in Indonesia.

Methods: Advanced analysis of secondary data from "Data and Information: Indonesian Health Profile in 2017". The analysis unit in this study was the province, all 34 provinces in Indonesia were analyzed. The dependent variable was the Number of Doctors. Dependent variables were the number of population, density, percentage of poor people, number of hospitals, and number of the Community Health Center.

Results: Variability in the availability of doctors was very wide. The more the population, the more attractive it was for doctors to practice in the province. The denser the population, the more attractive it was for doctors to practice. The more hospitals, the more attractive it was for doctors to practice in the province. The more Community Health Center, the more attractive it was for doctors to practice in the province.

Conclusions: Based on the results of the study, it can be concluded that from the five independent variables studied, there were four variables related to the number of doctors. Variables of population, density, number of hospitals, and number of the Community Health Center were positively related to the number of doctors. The results of this study were important as a basis for the policy of the doctors' redistribution in Indonesia.
\end{abstract}

Keywords: distribution analysis, doctors distribution, health resources management, health worker

\section{ABSTRAK}

Pendahuluan: Distribusi tenaga kesehatan menjadi kajian penting di Indonesia yang memiliki rentang geografis yang luas, dan tantangan sebagai negara kepulauan bagi terpenuhinya pelayanan kesehatan yang adil dan merata untuk seluruh masyarakat tanpa kecuali.

Tujuan: Penelitian dilakukan untuk menjawab faktor-faktor yang berkaitan dengan distribusi tenaga dokter berdasarkan provinsi di Indonesia.

Metode: Analisis lanjut data sekunder dari "Data dan Informasi: Profil Kesehatan Indonesia tahun 2017". Unit analisis dalam studi ini adalah provinsi, seluruh 34 provinsi di Indonesia dianalisis. Variabel dependen Jumlah Tenaga Dokter. Variabel dependen adalah jumlah penduduk, densitas, persentase penduduk miskin, jumlah rumah sakit, dan jumlah Puskesmas.

Hasil: Variabilitas ketersediaan tenaga dokter yang sangat lebar. Semakin banyak jumlah penduduk, semakin menarik bagi para tenaga dokter untuk berpraktik di provinsi tersebut. Semakin padat penduduk, semakin menarik bagi para tenaga dokter untuk berpraktik di provinsi tersebut. Semakin banyak rumah sakit, semakin menarik bagi para tenaga dokter untuk berpraktik di provinsi tersebut. Semakin banyak Puskesmas, semakin menarik bagi para tenaga dokter untuk berpraktik di provinsi tersebut.

Kesimpulan: Berdasarkan hasil penelitian, dapat disimpulkan bahwa dari lima variabel independen yang diteliti, ada empat variabel yang terkait dengan jumlah dokter. Variabel jumlah penduduk, densitas atau kepadatan penduduk, jumlah rumah sakit, dan jumlah Puskesmas berhubungan secara positif dengan jumlah tenaga dokter. Hasil penelitian ini dinilai penting sebagai dasar kebijakan untuk melakukan redistribusi tenaga dokter di Indonesia.

Kata kunci: analisis distribusi, distribusi tenaga dokter, manajemen sumberdaya kesehatan, tenaga kesehatan

\section{INTRODUCTION}

The distribution of health workers is an important study for a country like Indonesia, which has a broad geographical reach and is shaped as an archipelago, for the fulfillment of fair and equitable health services for the whole community without exception. The government has an interest in ensuring equality and improving health status in all regions of Indonesia. Especially in peripheral, remote, border and island areas which until now have not been well served (Suharmiati, Laksono and Astuti, 2013; Senewe and Elsi, 2014; Soewondo et al., 2019).

In the National Long Term Development Plan (RPJP-N) 2005-2025, it was stated that in realizing quality and competitiveness of human resources, health is one of the main pillars in improving the quality of human resources and the 
Indonesian Human Development Index. In the RPJP$\mathrm{N}$ it is also stated that national development in the health sector is directed at increasing awareness, willingness and the ability to live healthy for everyone so that the highest degree of health can be realized. Health workers, including doctors, are the main key in achieving health development goals, health workers contribute fully up to $80 \%$ in overall health development acceleration (Tangcharoensathien, Mills and Palu, 2015).

Governments in various countries are currently making efforts to achieve health equality, especially for people who are considered vulnerable and disadvantaged. The biggest challenge that must be faced is ensuring that people living in peripheral, backward and remote areas must also have access to health services to competent health workers or adequate health care facilities. The distribution of doctors in Indonesia raises the issue of equal rights for every citizen. Equality is expressed as no difference between groups of people, whether the group is defined socially, economically, demographically or geographically (Bambra, 2016).

Health inequality, especially the availability of doctors, more than involves health determinants, community access to health care facilities, but also related to the failure of a state government to overcome inequality, which is included in violations of the norms of justice and human rights human (Fu et al., 2018)(Tayyari Dehbarez et al., 2018). Problems with distribution and geographical imbalance add to the challenges faced by the government. Distributing and placing health workers in disadvantaged areas with adequate numbers and quality is very important in providing health services. There is still a huge disparity in Indonesia, between urban-rural areas (Laksono, Wulandari and Soedirham, 2019b)(Wulandari and Laksono, 2019), between regions, up to between districts and provinces in Indonesia (Laksono, Wulandari and Soedirham, 2019a). Data obtained from BPPSDMK in 2019 explain the distribution of health workers can be seen from the ratio of doctors in the DKI Jakarta area of 65 per 100,000 population while in West Java and Banten 11 per 100,000 population. Disparities are also seen in West Sulawesi province with 12 per 100,000 population and followed by Maluku and East Nusa Tenggara (NTT) of 14 per 100,000 population.

The problem of the distribution of doctors according to population ratios is a problem involving geographical and demographic trends. Especially access to basic health services that require more attention in terms of geography. Special efforts or policies are still needed to deal with the problem of doctor distribution, especially in the era of National Health Insurance (Karan et al., 2019). The purpose of this study is to answer any factors related to the distribution of doctors by the province in Indonesia.

\section{METHODS}

This study was an analysis of secondary data. Secondary data was taken from data sources "Data and Information: Indonesian Health Profile 2017" issued by the Health Data and Information Center, Ministry of Health of the Republic of Indonesia (Kementerian Kesehatan RI., 2018). The profile book was provided on the link www.pusdatin.kemkes.go.id. The analysis unit in this study was the province. In total 34 provinces in Indonesia were analyzed in a study of the distribution of these doctors.

The dependent variable that will be predicted was "Number of Doctors". The number of doctors was a large number of doctors, both general and specialist, who practice in certain provinces. There were 5 other variables analyzed related to "Number of Physicians". The five variables were population, density, percentage of poor people, number of hospitals, and number of Puskesmas (the Community Health Center). Each variable was categorized into 5 statistical distribution strata. This step was done to simplify the analysis by crosstabulating each variable with the variable "Number of Doctors".

\section{RESULTS}

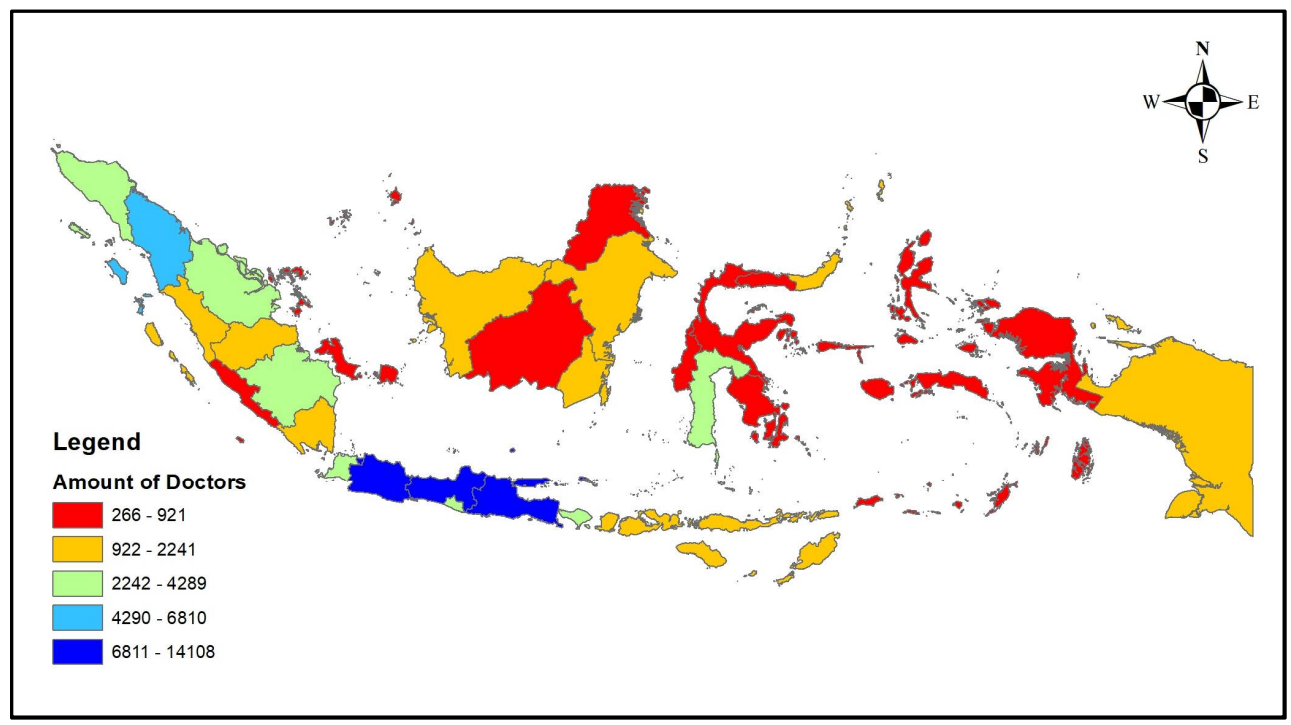

Figure 1. Distribution of Doctors Numbers based on Provinces in Indonesia in 2017 


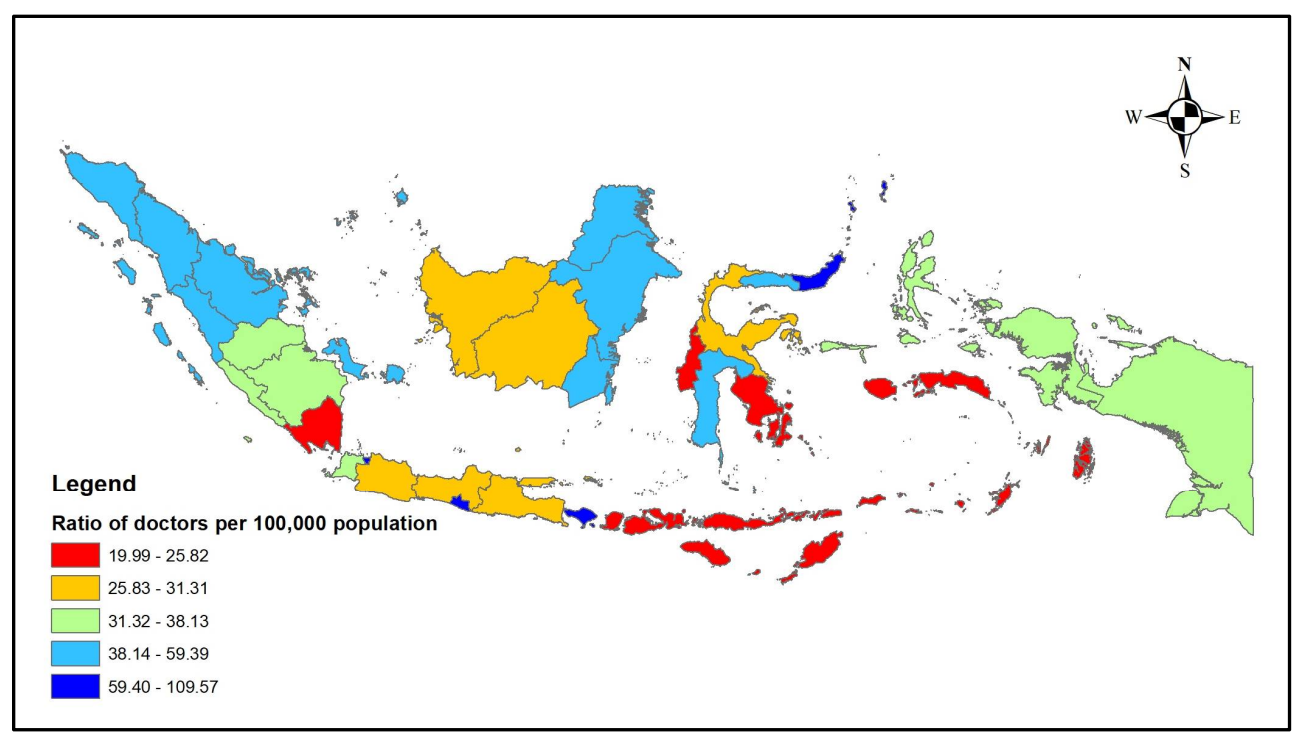

Figure 2. Distribution of Doctors Ratio per 100.000 Population, based on Provinces in Indonesia in 2017

Table 1. Descriptive Statistics of Number of Doctors and other related variables

\begin{tabular}{|l|r|r|r|r|r|}
\hline \multicolumn{1}{|c|}{ Variables } & \multicolumn{1}{c|}{ N } & \multicolumn{1}{c|}{ Min } & \multicolumn{1}{c|}{ Max } & \multicolumn{1}{c|}{ Mean } & \multicolumn{1}{c|}{ Std Deviation } \\
\hline Number of doctors & 34 & 266 & 14108 & 2932.44 & 3632.620 \\
\hline Number of Populations & 34 & 691,058 & 48037,827 & $7,702,672.71$ & $11,003,254.853$ \\
\hline Percentage of Poor Population & 34 & $3.78 \%$ & $27.76 \%$ & $10.95 \%$ & 0.0578730 \\
\hline Population Density & 34 & 9.16 & $15,623.61$ & 727.1847 & $2,661.62002$ \\
\hline Number of hospitals & 34 & 10 & 393 & 81.65 & 96.411 \\
\hline $\begin{array}{l}\text { Number of Community Health } \\
\text { Center }\end{array}$ & 34 & 49 & 1056 & 288.97 & 243.159 \\
\hline
\end{tabular}

Table 2. Cross Tabulation of Number of Doctors and Population in Indonesia 2017

\begin{tabular}{|c|c|c|c|c|c|c|}
\hline \multirow{2}{*}{$\begin{array}{l}\text { Number of } \\
\text { Populations }\end{array}$} & \multicolumn{5}{|c|}{ Number of Doctors } & \multirow{2}{*}{ Total } \\
\hline & $<637$ & $637-1,125$ & $1,126-2,059$ & $2,060-3,708$ & $>3,708$ & \\
\hline \multirow{2}{*}{$<1,744,654$} & 7 & 0 & 0 & 0 & 0 & 7 \\
\hline & $100.0 \%$ & $0.0 \%$ & $0.0 \%$ & $0.0 \%$ & $0.0 \%$ & $100.0 \%$ \\
\hline \multirow{2}{*}{ 1,744,654 - 3,265,202 } & 0 & 6 & 1 & 0 & 0 & 7 \\
\hline & $0.0 \%$ & $85.7 \%$ & $14.3 \%$ & $0.0 \%$ & $0.0 \%$ & $100.0 \%$ \\
\hline \multirow{2}{*}{$3,265,203-4,955,578$} & 0 & 0 & 5 & 2 & 0 & 7 \\
\hline & $0.0 \%$ & $0.0 \%$ & $71.4 \%$ & $28.6 \%$ & $0.0 \%$ & $100.0 \%$ \\
\hline \multirow{2}{*}{$4,955,579-8,690,294$} & 0 & 1 & 1 & 5 & 0 & 7 \\
\hline & $0.0 \%$ & $14.3 \%$ & $14.3 \%$ & $71.4 \%$ & $0.0 \%$ & $100.0 \%$ \\
\hline \multirow{2}{*}{$>8,690,294$} & 0 & 0 & 0 & 0 & 6 & 6 \\
\hline & $0.0 \%$ & $0.0 \%$ & $0.0 \%$ & $0.0 \%$ & $100.0 \%$ & $100.0 \%$ \\
\hline
\end{tabular}

Figure 1 shows the distribution of the absolute number of doctors available per province in Indonesia. It appears that the absolute number of doctors is the most practiced in Java Island. While in Western Indonesia, Indonesia tends to have more doctors available than in Eastern Indonesia.

Table 2 is a cross-tabulation between the number of doctors and the population in the province. In the category of very few populations $(<1,744,654$
In Figure 2, which maps the distribution of the ratio of doctors per 100,000 population, the conditions shown are different. Some provinces on Java Island have a lower ratio. This is because the effect of the population is more than the area on other islands.

people) it was seen as a whole occupied by the number of doctors who were also included in very few categories ( $<637$ doctors). While in the category 
of a very large population (> 8,690,294 people), it was seen as a whole occupied by the number of doctors in the very large category ( $>3,708$ doctors). This means that the number of doctors is positively related to the population in a province. The more the population, the more attractive it is for doctors to practice in the province.

Table 3 is a cross-tabulation between the number of doctors with density or population density in the province. In the category of very non-dense density (<37.19 people per kilometer) it was seen to be dominated by the number of doctors who were also in very few categories (<637 doctors). While in the very dense density category (> 734.69 people per kilometer), it was seen to be dominated by the number of doctors in the very large category $(>3,708$ doctors). This means that the number of doctors is positively associated with population density in a province. The denser the population, the more attractive it is for doctors to practice in the province.

Table 4 is a cross-tabulation between the number of doctors and the percentage of poor people in the province. In the category of the percentage of poor people, very few $(<6.08 \%$ poor people) are seen to be dominated by the number of doctors who also fall into a very small category ( $<637$ doctors). While in the category of the percentage of poor people is very large (> $15.58 \%$ poor people), it appears to be dominated by the number of doctors in the very large category (> 3,708 doctors). But different trends are shown in other categories. The percentage of poor people in the medium category is dominated by the number of doctors in the large category. While the percentage of poor people in a large category is dominated by the number of doctors in the medium category.

Table 5 is a cross-tabulation between the number of doctors and the number of hospitals in the province. In the category of very few hospitals $(<22$ hospitals), it was seen to be dominated by the number of doctors who were also in very few categories ( $<637$ doctors). While in the category of the number of very many hospitals (> 100 hospitals), it was seen as a whole occupied by the number of doctors in the very large category (> 3,708 doctors). This means that the number of doctors is positively related to the number of hospitals in a province. The more hospitals, the more attractive it is for doctors to practice in the province.

Table 3. Cross Tabulation of Number of Doctors and Population Density per Kilometer in Indonesia 2017

\begin{tabular}{|c|c|c|c|c|c|c|}
\hline \multirow{2}{*}{ Density } & \multicolumn{5}{|c|}{ Number of Doctors } & \multirow{2}{*}{ Total } \\
\hline & $<637$ & $637-1,125$ & $1,126-2,059$ & $2,060-3,708$ & $>3,708$ & \\
\hline \multirow{2}{*}{$<37.19$} & 3 & 2 & 2 & 0 & 0 & 7 \\
\hline & $42.9 \%$ & $28.6 \%$ & $28.6 \%$ & $0.0 \%$ & $0.0 \%$ & $100.0 \%$ \\
\hline \multirow{2}{*}{$37.19-87.12$} & 3 & 2 & 1 & 1 & 0 & 7 \\
\hline & $42.9 \%$ & $28.6 \%$ & $14.3 \%$ & $14.3 \%$ & $0.0 \%$ & $100.0 \%$ \\
\hline \multirow{2}{*}{$87.13-126.66$} & 1 & 2 & 1 & 3 & 0 & 7 \\
\hline & $14.3 \%$ & $28.6 \%$ & $14.3 \%$ & $42.9 \%$ & $0.0 \%$ & $100.0 \%$ \\
\hline \multirow{2}{*}{$126.67-734.69$} & 0 & 1 & 3 & 2 & 1 & 7 \\
\hline & $0.0 \%$ & $14.3 \%$ & $42.9 \%$ & $28.6 \%$ & $14.3 \%$ & $100.0 \%$ \\
\hline \multirow{2}{*}{$>734.69$} & 0 & 0 & 0 & 1 & 5 & 6 \\
\hline & $0.0 \%$ & $0.0 \%$ & $0.0 \%$ & $16.7 \%$ & $83.3 \%$ & $100.0 \%$ \\
\hline
\end{tabular}

Table 4. Cross Tabulation Number of Doctors and Percentage of Poor Population in Indonesia in 2017

\begin{tabular}{|c|c|c|c|c|c|c|}
\hline \multirow{2}{*}{$\begin{array}{l}\text { Persentase Poor } \\
\text { Populations }\end{array}$} & \multicolumn{5}{|c|}{ Number of Doctors } & \multirow{2}{*}{ Total } \\
\hline & $<637$ & $637-1,125$ & $1,126-2,059$ & $2,060-3,708$ & $>3,708$ & \\
\hline \multirow{2}{*}{$<6.08 \%$} & 3 & 2 & 2 & 0 & 0 & 7 \\
\hline & $42.9 \%$ & $28.6 \%$ & $28.6 \%$ & $0.0 \%$ & $0.0 \%$ & $100.0 \%$ \\
\hline \multirow{2}{*}{$6.08 \%-7.86 \%$} & 3 & 2 & 1 & 1 & 0 & 7 \\
\hline & $42.9 \%$ & $28.6 \%$ & $14.3 \%$ & $14.3 \%$ & $0.0 \%$ & $100.0 \%$ \\
\hline \multirow{2}{*}{$7.87 \%-11.97 \%$} & 1 & 2 & 1 & 3 & 0 & 7 \\
\hline & $14.3 \%$ & $28.6 \%$ & $14.3 \%$ & $42.9 \%$ & $0.0 \%$ & $100.0 \%$ \\
\hline \multirow{2}{*}{$11.98 \%-15.58 \%$} & 0 & 1 & 3 & 2 & 1 & 7 \\
\hline & $0.0 \%$ & $14.3 \%$ & $42.9 \%$ & $28.6 \%$ & $14.3 \%$ & $100.0 \%$ \\
\hline \multirow{2}{*}{$>15.58 \%$} & 0 & 0 & 0 & 1 & 5 & 6 \\
\hline & $0.0 \%$ & $0.0 \%$ & $0.0 \%$ & $16.7 \%$ & $83.3 \%$ & $100.0 \%$ \\
\hline
\end{tabular}


Table 6 is a cross-tabulation between the number of doctors and the number of the Community Health Center in the province. In the category of the number of the Community Health Center, very few $(<121$ Health Center) were seen to be dominated by the number of doctors who were also in very few categories (<637 doctors). While in the category of the number of the Community Health Center very much (> 372 Community Health Center), it was seen as a whole occupied by the number of doctors in the very category ( $>3,708$ doctors). This means that the number of doctors is positively related to the number of the Community Health Center in a province. The more the Community Health Center, the more attractive it is for doctors to practice in the province.

Table 5. Cross Tabulation of Number of Doctors and Number of Hospitals in Indonesia in 2017

\begin{tabular}{|c|c|c|c|c|c|c|}
\hline \multirow{2}{*}{$\begin{array}{c}\text { Number of } \\
\text { Hospitals }\end{array}$} & \multicolumn{5}{|c|}{ Number of Doctors } & \multirow{2}{*}{ Total } \\
\hline & $<637$ & $637-1,125$ & $1,126-2,059$ & $2,060-3,708$ & $>3,708$ & \\
\hline \multirow{2}{*}{$<22$} & 6 & 2 & 0 & 0 & 0 & 8 \\
\hline & $75.0 \%$ & $25.0 \%$ & $0.0 \%$ & $0.0 \%$ & $0.0 \%$ & $100.0 \%$ \\
\hline \multirow{2}{*}{$22-35$} & 1 & 3 & 2 & 0 & 0 & 6 \\
\hline & $16.7 \%$ & $50.0 \%$ & $33.3 \%$ & $0.0 \%$ & $0.0 \%$ & $100.0 \%$ \\
\hline \multirow{2}{*}{$36-63$} & 0 & 2 & 4 & 1 & 0 & 7 \\
\hline & $0.0 \%$ & $28.6 \%$ & $57.1 \%$ & $14.3 \%$ & $0.0 \%$ & $100.0 \%$ \\
\hline \multirow{2}{*}{$64-100$} & 0 & 0 & 1 & 6 & 0 & 7 \\
\hline & $0.0 \%$ & $0.0 \%$ & $14.3 \%$ & $85.7 \%$ & $0.0 \%$ & $100.0 \%$ \\
\hline \multirow{2}{*}{$>100$} & 0 & 0 & 0 & 0 & 6 & 6 \\
\hline & $0.0 \%$ & $0.0 \%$ & $0.0 \%$ & $0.0 \%$ & $100.0 \%$ & $100.0 \%$ \\
\hline
\end{tabular}

Table 6. Cross Tabulation of Number of Doctors and Number of the Community Health Center in Indonesia in 2017

\begin{tabular}{|c|c|c|c|c|c|c|}
\hline \multirow{2}{*}{$\begin{array}{c}\text { Number of } \\
\text { Community Health } \\
\text { Center }\end{array}$} & \multicolumn{5}{|c|}{ Number of Doctors } & \multirow{2}{*}{ Total } \\
\hline & $<637$ & $637-1,125$ & $1,126-2,059$ & $2,060-3,708$ & $>3,708$ & \\
\hline \multirow{2}{*}{$<121$} & 4 & 1 & 0 & 2 & 0 & 7 \\
\hline & $57.1 \%$ & $14.3 \%$ & $0.0 \%$ & $28.6 \%$ & $0.0 \%$ & $100.0 \%$ \\
\hline \multirow{2}{*}{$121-189$} & 2 & 1 & 4 & 0 & 0 & 7 \\
\hline & $28.6 \%$ & $14.3 \%$ & $57.1 \%$ & $0.0 \%$ & $0.0 \%$ & $100.0 \%$ \\
\hline \multirow{2}{*}{$190-241$} & 1 & 2 & 2 & 1 & 1 & 7 \\
\hline & $14.3 \%$ & $28.6 \%$ & $28.6 \%$ & $14.3 \%$ & $14.3 \%$ & $100.0 \%$ \\
\hline \multirow{2}{*}{$242-372$} & 0 & 2 & 1 & 3 & 1 & 7 \\
\hline & $0.0 \%$ & $28.6 \%$ & $14.3 \%$ & $42.9 \%$ & $14.3 \%$ & $100.0 \%$ \\
\hline \multirow{2}{*}{$>372$} & 0 & 1 & 0 & 1 & 4 & 6 \\
\hline & $0.0 \%$ & $16.7 \%$ & $0.0 \%$ & $16.7 \%$ & $66.7 \%$ & $100.0 \%$ \\
\hline
\end{tabular}

\section{DISCUSSION}

The results showed that the distribution of the availability of doctors among provinces showed very wide variability in the availability of doctors. West Sulawesi Province has at least 266 doctors. While in West Java Province the number of doctors reached 14,108 doctors. The results also show that the number of doctors is positively related to population, density, number of hospital and number of the Community Health Center. This condition is the impact of health service policies issued by the government. Until 2014 the policy on the Community Health Center was regulated with a standard ratio for a Community Health Center that was per 30,000 residents. Due to the progressive development of the new Community Health Center in 2014, the ratio of the Community Health Center was changed to per district. The standard ratio of the establishment of the Community Health Center is valid until now. Although the quota for the number of doctors in Indonesia has exceeded the quota, there are still more than 700 Community Health Centers that lack doctors. This is due to the uneven distribution of human resources, which often accumulates in Java-Bali (Kementerian Kesehatan RI., 2019).

The health policy that is still related to the distribution of the health workforce is the Minister of Health Regulation 75/2014 on the Community Health Center which regulates the minimum number of health workers, including doctors, which must be 
available at the Community Health Center. This policy in detail calculates the needs of health workers in the Community Health Center based on staff workload analysis, taking into account the large number of health services they have and provide, population size and distribution, characteristics of the work area, work area, availability of other health facilities in the work area, and the division of labor time (Anak Agung Ngurah Gede Dharmayuda, Wulandari and Wirawan, 2015; Anorital, Muljati and Andayasari, 2016; Marlinda, 2017; Hidayanti, 2018).

The Minister of Health Regulation 75/2014 is also the basis for the issuance of other policies, The Minister of Health Regulation 33/2018 concerning the Healthy Nusantara Program. The Healthy Nusantara Program policy was issued to meet the needs of several health centers in disadvantaged areas, borders, and islands, where the number of health workers was not in accordance with the standard (Laksono, 2016; Ardi Taufik Simanjuntak, Kusmanto and Suriadi, 2018). This policy is an effort to distribute doctors and other health workers in peripheral areas. Areas where health workers are rarely interested. Doctors can be distributed in two ways; through a team-based mechanism, together with other health workers; or individually, in accordance with Non-Permanent Employee (PTT) programs.

In addition, the government also gives special attention and separate policies for disadvantaged areas, borders, and disadvantaged islands. The government released mobile hospitals, border hospitals, mobile hospitals, flying doctors, and water services, including health financing distribution policies (Laksono et al., 2014; Pratiwi et al., 2014; Misnaniarti et al., 2017; Prawiroharjo, Pratama and Librianty, 2019). Although apparently there is still a need for other health policy support for the redistribution of doctors in Indonesia.

In addition to the macro variables examined in this article, there are several regional conditions that are attractive for doctors to come to. Some other conditions that have an effect are regional fiscal capacity, regional original income, gross regional domestic income, economic growth, and the percentage of the budget for the health sector (Wahab, Husein and Al-Hadithi, 2016; Thomson, 2019; Mclsaac, Scott and Kalb, 2019). The results of research conducted in Blitar District recommend an incentive pattern for doctors by considering the level of difficulty of the region, topography, and availability of transportation, as well as the conditions of access to the location of the work area. Recommendations in the research were formulated in discussions involving doctors, heads of Health Centers, Regional Hospitals, Health Offices, members of the Regional People's Representative Council (DPRD), the Regional Personnel Agency (BKD), and the Regional Development Planning Agency (Bappeda)(Laksono, Pudjirahardjo and Mulyono, 2012).

The findings of this study are in line with the latest research findings in India (Singh, 2019; Karan et al., 2019) and China (Zhu, Hsieh and Mao, 2019). The results of the study in the two regions found the same research facts, that the distribution of physicians was influenced by the population in an area. This includes the level of population density.
Disparities in the distribution of physicians in the Indian region and China were also found to be in line with the widening of the Gini index (Singh, 2019)(Yang, Yin and Wang, 2019)(Wu and Yang, 2019).

Slightly different from the findings in this study, in Lebanon doctors are less interested in primary care service (the Community Health Center). Doctors in Lebanon prefer to practice independently in urban areas. There are at least five main problems that cause doctors not to be interested in primary services, namely low understanding of concepts, scope of work in primary services, recruitment issues, problems with low doctor retention and challenges faced by doctors working in remote areas and retarded, and the role of their policymakers (Alameddine et al., 2016). Retention of doctors especially those working in primary services is low due to low income. The capitation system that is used as the basis for payment of medical services is difficult for doctors who work in remote areas, especially with diffuse geographical and demographic conditions. A difficult work environment and does not guarantee social life is also a separate obstacle (Laksono, Nantabah and Wulandari, 2018; Bertone, Lurton and Mutombo, 2016; Honda et al., 2019; Mashange et al., 2019).

The reluctance of doctors to work in rural and remote areas far from cities is a challenge that must be faced. Such ongoing conditions make access to health services in urban areas far better than in rural areas (Kenea and Jisha, 2017; Wen et al., 2017; Gonzales et al., 2017; Li et al., 2018). The Eastern Indonesia region, with the dominance of rural areas, inadequate facilities, and areas with low population density, is one reason for the reluctance (barrier) for doctors and other health workers to enter and practice in the region (Nantabah, Agustina and Laksono, 2019).

The facts found as a result in this study are of limited usefulness as inputs to macro policy, because the data analyzed is aggregate data at the provincial level. Further research is still needed to find out the reasons at the individual level, both individual doctors as implementers, and individual communities as policy targets. This is needed as a basis for making more detailed policy decisions at the micro-level.

\section{CONCLUSION}

Based on the results of the study, it can be concluded that from the five independent variables studied, there were four variables related to the number of doctors. Variables in population size, density or population density, number of hospitals, and number of health centers are positively related to the number of doctors. The government needs to issue a policy of redistribution of medical placement in Indonesia. The policy to withdraw and retention of doctors in the minus region can be in the form of rewards, both material and non-material. For example, guaranteeing the ease of specialist schools for doctors serving in the area.

\section{ACKNOWLEDGMENTS}

The author would like to thank the Center for Data and Information, the Ministry of Health of the 
Republic of Indonesia, which has provided data on the Indonesian Health Profile in 2017 which is the basis of the analysis of this study.

\section{REFERENCES}

Alameddine, M. et al. (2016) 'Upscaling the recruitment and retention of human resources for health at primary healthcare centres in Lebanon: a qualitative study', Health Soc Care Community, 24(3), pp. 353-362. doi: 10.1111/hsc. 12210.

Anak Agung Ngurah Gede Dharmayuda, Wulandari, L. P. L. and Wirawan, D. N. (2015) 'Workload Analysis of Doctors at Puskesmas Using Workload Indicators of Staffing Need in Denpasar', Public Health and Preventive Medicine Archive, 3(1), pp. 16-21. doi: 10.15562/phpma.v3i1.95.

Anorital, A., Muljati, S. and Andayasari, L. (2016) 'Overview of The Availability of Human Resources and Dental Health Services in Indonesian Public Health Centers', Buletin Penelitian Kesehatan, 44(3), pp. 197-204. doi: 10.22435/bpk.v44i3.5297.197-204.

Ardi Taufik Simanjuntak, Kusmanto, $\mathrm{H}$. and Suriadi, A. (2018) 'Efektivitas Program Nusantara Sehat Pada Puskesmas Tanjung Beringin, Kecamatan Tanjung Beringin Kabupaten Serdang Bedagai', Anthropos: Jurnal Antropologi Sosial dan Budaya, 4(1), pp. 92107. doi: 10.24114/antro.v4i1.10156.

Bambra, C. (2016) Health Divides: where you live can kill you. Bristol: Policy Press.

Bertone, M. P., Lurton, G. and Mutombo, P. B. (2016) 'Investigating the remuneration of health workers in the DR Congo: Implications for the health workforce and the health system in a fragile setting', Health Policy and Planning, 31(9), pp. 1143-1151. doi: 10.1093/heapol/czv131.

$\mathrm{Fu}, \mathrm{X}$. et al. (2018) 'Influencing factors of inequity in health services utilization among the elderly in China 14 Economics 1402 Applied Economics 11 Medical and Health Sciences 1117 Public Health and Health Services', International Journal for Equity in Health, 17(1). doi: 10.1186/s12939-018-0861-6.

Gonzales, S. et al. (2017) 'Progressive rural-urban disparity in acute stroke care', Neurology, 88(5), pp. 441-448. doi: 10.1212/WNL.0000000000003562.

Hidayanti, H. (2018) 'Distribution of Health Workers in Lamongan District', Cakrawala, 12(2), pp. 162-177. doi: 10.32781/cakrawala.v12i2.272.

Honda, A. et al. (2019) 'For more than money: Willingness of health professionals to stay in remote Senegal', Human Resources for Health, 17(1), p. Article number 28. doi: 10.1186/s12960-019-0363-7.

Karan, A. et al. (2019) 'Size, composition and distribution of human resource for health in India: new estimates using National Sample Survey and Registry data', BMJ open, 9(4), p. Page e025979. doi: 10.1136/bmjopen-2018025979.

Kementerian Kesehatan RI. (2018) Data dan Informasi: Profil Kesehatan Indonesia tahun
2017. Jakarta: Kementerian Kesehatan RI.

Kementerian Kesehatan RI. (2019) Profil Kesehatan Indonesia Tahun 2018. Jakarta. Available at: http://www.depkes.go.id/resources/download /pusdatin/profil-kesehatan-indonesia/Datadan-Informasi_Profil-Kesehatan-Indonesia2018.pdf.

Kenea, D. and Jisha, H. (2017) 'Urban-rural disparity and determinants of delivery care utilization in Oromia region, Ethiopia: Community-based cross-sectional study', International Journal of Nursing Practice, 23(1). doi: 10.1111/ijn.12510.

Laksono, A. D. et al. (2014) Muyu women in exile (Perempuan Muyu dalam Pengasingan). Jakarta: Lembaga Penerbitan Balitbangkes. Available https://www.scribd.com/doc/261673624/Pere mpuan-Muyu-dalam-Pengasingan-RisetEthnografi-Kesehatan-2014-Boven-Digoel.

Laksono, A. D. (2016) 'Health Care Accessibility (Aksesibilitas Pelayanan Kesehatan)', in Supriyanto, S., Chalidyanto, D., and Wulandari, R. D. (eds) Aksesibilitas Pelayanan Kesehatan di Indonesia. Jogjakarta: PT Kanisius, pp. 5-20.

Laksono, A. D., Nantabah, Z. K. and Wulandari, R. D. (2018) 'Access Barriers to Health Center for Elderly in Indonesia', Buletin Penelitian Sistem Kesehatan, 21(4), pp. 228-235. doi: 10.22435/hsr.v2li4.887.

Laksono, A. D., Pudjirahardjo, W. J. and Mulyono, I. M. (2012) Analisis Kebijakan Ketenagaan: Sebuah Formulasi Kebijakan Ketenagaan Dokter Umum. Surabaya: Health Advocacy.

Laksono, A. D., Wulandari, R. D. and Soedirham, O. (2019a) 'Regional Disparities of Health Center Utilization in Rural Indonesia', Malaysian Journal of Public Health Medicine, 19(1).

Laksono, A. D., Wulandari, R. D. and Soedirham, O. (2019b) 'Urban and Rural Disparities in Hospital Utilization among Indonesian Adults', Iranian Journal of Public Health, 48(2), pp. 247-255. Available at: http://ijph.tums.ac.ir/index.php/ijph/article/vie $\mathrm{w} / 16143$.

$\mathrm{Li}$, J. et al. (2018) 'Urban-rural disparities in health care utilization among Chinese adults from 1993 to 2011', BMC health services research, 18(102), pp. 1-9. doi: 10.1186/s12913-0182905-4.

Marlinda, P. (2017) 'Analisis Perencanaan Kebutuhan Tenaga Dokter oleh Dinas Kesehatan Kota Pekanbaru', Jurnal Niara, 9(2), pp. 71-83. doi: 10.31849/nia.v9i2.2100.

Mashange, W. et al. (2019) 'Flexibility of deployment: Challenges and policy options for retaining health workers during crisis in Zimbabwe', Human Resources for Health, 17(1), p. Article number 39. doi: 10.1186/s12960-019-0369-1.

Mclsaac, M., Scott, A. and Kalb, G. (2019) 'The role of financial factors in the mobility and location choices of General Practitioners in Australia', Human Resources for Health, 17(1), p. Article number 34. doi: 10.1186/s12960-019-0374-4.

Misnaniarti et al. (2017) 'Ketersediaan Fasilitas dan Tenaga Kesehatan Dalam Mendukung 
Cakupan Semesta Jaminan Kesehatan Nasional', Jurnal Penelitian dan Pengembangan Pelayanan Kesehatan, 1(1), pp. 6-16. doi: 10.22435/jpppk.v1i1.425.

Nantabah, Z. K., Agustina, Z. A. and Laksono, A. D. (2019) 'GAMBARAN AKSES PELAYANAN KESEHATAN PADA BALITA DI INDONESIA', Buletin Penelitian Sistem Kesehatan, 22(1), pp. 54-61. doi: 10.22435/hsr.v22i1.439.

Pratiwi, N. L. et al. (2014) 'Kajian Kebijakan Penyaluran Dana Bantuan Operasional Kesehatan dalam Mendukung Pencapaian Kesehatan Ibu dan Anak (MDG's 4,5) di Tiga Kabupaten, Kota di Provinsi Jawa Timur Indonesia', Buletin Penelitian Sistem Kesehatan, 17(4), pp. 395-405.

Prawiroharjo, P., Pratama, P. and Librianty, N. (2019) 'Layanan Telemedis di Indonesia: Keniscayaan, Risiko, dan Batasan Etika', Jurnal Etika Kesehatan Indonesia, 3(1), p. 109. doi: $10.1017 /$ S0963180108080535.

Senewe, F. P. and Elsi, E. (2014) 'DESCRIPTIVE ANALYSIS TO ENVIRONMENT HEALTH IN LESS DEVELOPMENT, BORDERLANDS, ARCHIPELAGOES AND REMOTE AREAS (DTPK-T)', Media Litbangkes, 24(3), pp. 153160. doi: $10.22435 / \mathrm{mpk} . v 24 i 3.3650 .153-160$.

Singh, A. (2019) 'Shortage and inequalities in the distribution of specialists across community health centres in Uttar Pradesh, 2002-2012', BMC Health Services Research, 19(1), p. Article number 331. doi: 10.1186/s12913-0194134-x.

Soewondo, P. et al. (2019) 'INSPECTING PRIMARY HEALTHCARE CENTERS IN REMOTE AREAS: FACILITIES, ACTIVITIES, AND FINANCES', Jurnal Administrasi Kesehatan Indonesia, 7(1), pp. 89-98. doi: 10.20473/jaki.v7i1.2019.89-98.

Suharmiati, Laksono, A. D. and Astuti, W. D. (2013) 'Policy Review on Health Services in Primary Health Center in the Border and Remote Area', Bulletin of Health System Research, 16(2), pp. 109-116.

Tangcharoensathien, V., Mills, A. and Palu, T. (2015) 'Accelerating health equity: The key role of universal health coverage in the Sustainable Development Goals', BMC Medicine, 13(1), p. Article number 101. doi: 10.1186/s12916-0150342-3.

Tayyari Dehbarez, N. et al. (2018) 'Does free choice of hospital conflict with equity of access to highly specialized hospitals? A case study from the Danish health care system', Health Policy. doi: 10.1016/j.healthpol.2018.04.006.

Thomson, M. (2019) Who had access to doctors before and after new universal capitated subsidies in New Zealand?', Health Policy, 123(8), pp. 756-764. doi: 10.1016/j.healthpol.2019.04.004.

Wahab, M. A., Husein, V. M. and Al-Hadithi, T. S. (2016) 'Distribution of doctors' workforce in Erbil Governorate', Zanko Journal of Medical Science, 20(1), p. 1138 1146. doi: 10.15218/zjms.2016.0001.

Wen, P.-C. et al. (2017) 'Demographic and ruralurban variations in dental service utilization in Taiwan', Rural and Remote Health, 17(3). doi: 10.22605/RRH4161.

$\mathrm{Wu}, \mathrm{J}$. and Yang, Y. (2019) 'Inequality trends in the demographic and geographic distribution of health care professionals in China: Data from 2002 to 2016', International Journal of Health Planning and Management, 34(1), pp. e487e508. doi: 10.1002/hpm.2664.

Wulandari, R. D. and Laksono, A. D. (2019) 'UrbanRural Disparities in The Utilization of Primary Health Care Center Among Elderly in East Java, Indonesia', Jurnal Administrasi Kesehatan Indonesia, 7(2), p. in press. doi: 10.20473/jaki.v7i2.2019.\%25p.

Yang, L., Yin, Y. and Wang, H. (2019) 'Is the health workforce distribution in Beijing, China perfectly equitable?', Ethiopian Journal of Health Development, 33(1), pp. 22-27.

Zhu, B., Hsieh, C.-W. and Mao, Y. (2019) 'Addressing the Licensed Doctor Maldistribution in China: A Demand-AndSupply Perspective', International journal of environmental research and public health, 16(10), pp. 1-19. doi: 10.3390/ijerph16101753 